\title{
Integrated approach to solving the problems of land recovery and disposal of solid waste in the coal mining region
}

\author{
Ludmila Zakonnova ${ }^{1 *}$, Andrei Babenko ${ }^{2}$, Igor Nikishkin ${ }^{3}$, Zhanat Idrisheva ${ }^{4}$, and Rudi \\ Minasyan $^{1}$
}

${ }^{1}$ T.F. Gorbachev Kuzbass State Technical University, Belovo Branch, Ilyica st. 32, Belovo, Russia 652644

${ }^{2}$ National Research Tomsk State University, 36 Lenina Avenue, Tomsk, Russia, 634050

${ }^{3}$ Belovsky Fisheries LLC, Belovo, Russia

${ }^{4}$ D. Serikbayev East Kazakhstan Technical University, 69 Protozanov Street, Ust-Kamenogorsk, The Republic of Kazakhstan, 070004

\begin{abstract}
As a result of anthropogenic destruction of natural biogeocenoses, a decrease in biodiversity occurs, leading to instability and degradation of both individual elements and the biosphere as a whole. In coal-mining regions, there are two equivalent environmental problems: land degradation as a result of mining and an increase in production and consumption waste. The unfavorable ecological situation affects the state of the ecosystem of the regions as a whole, which negatively affects the health of the population. In this regard, the development of predictive models of the state of disturbed lands - their reclamation and return to the national economic turnover - are relevant. The purpose of this work is to develop principles of rational nature management during land reclamation in the Kemerovo region, disturbed as a result of opencast mining of mineral deposits. The principles of rational use have been developed, their implementation will contribute to the improvement of the ecological situation. The mechanisms of implementation include: an integrated approach to solving the problems of land reclamation and disposal of solid household waste in a coal-mining region; forecasting and regulation of the introduction of alien objects; introduction of environmentally friendly technologies to minimize emissions of xenobiotics into the biosphere and decontamination of MSW processing products.
\end{abstract}

\section{Introduction}

As a result of anthropogenic destruction of natural biogeocenoses, a decrease in biodiversity occurs, leading to instability and degradation of both individual elements and the biosphere as a whole. In coal-mining regions, there are two equivalent environmental problems: land degradation as a result of mining and an increase in production and

\footnotetext{
* Corresponding author: nir belovo@mail.ru
} 
consumption waste. The first problem is anthropogenic land degradation in coal-mining regions, leading to soil erosion, destruction of biocenoses, emission of greenhouse gases, and climate change. In this regard, the need for systematic reclamation of disturbed lands is a priority global problem of all resource-producing and resource-processing states $[4 ; 8 \mathrm{t}$; $10 ; 12 ; 13 ; 14 ; 15]$. The second problem is an increase in the volume of production and consumption waste, which, on the one hand, leads to the withdrawal from economic circulation of significant land areas for the creation of landfills for the storage of solid waste, on the other hand, due to the complexity of the disposal of certain types of waste, exacerbates the global crisis of decomposers, accompanied by the introduction of into the environment of a huge amount of xenobiotics, which threatens with catastrophic consequences on a planetary scale. The unfavorable ecological situation affects the state of the ecosystem of the regions as a whole, which negatively affects the health of the population. In this regard, the development of predictive models of the state of disturbed lands: their reclamation and return to the national economic turnover are relevant. The purpose of this work: development of principles of rational nature management during land reclamation in the Kemerovo region, disturbed as a result of opencast mining of mineral deposits.

\section{Materials and methods}

To analyze the dynamics of the state of disturbed lands and the volume of production and consumption waste, ecological maps of the Kemerovo region and statistical reports "On the state and protection of the environment of the Kemerovo region" were used. As a result of statistical processing of the information received, a "Forecast of the state of lands disturbed as a result of mining in Kuzbass" was compiled. A comparative analysis of biotechnological methods of reclamation of the fertile soil layer has been carried out. Were developed the author's principles of rational nature management during the reclamation of lands in the Kemerovo region, disturbed as a result of open-pit mining of mineral deposits.

\section{Results and discussion}

\section{Forecast of the state of lands disturbed as a result of mining in Kuzbass}

In the Russian Federation, work on reclamation of disturbed lands is regulated by the Land Code of the Russian Federation, the Federal Law "On Environmental Protection", orders of the Ministry of Natural Resources and the Government of the Russian Federation. The Land Code of the Russian Federation recognizes: "the priority of land protection as the most important component of the environment; the priority of protecting human life and health, according to which, when carrying out activities for the use and protection of lands, such decisions and activities should be taken that would ensure the preservation of human life or prevent negative (harmful) effects on human health, even if it requires high costs ". Reclamation of lands disturbed as a result of opencast mining of mineral deposits is a complex complex process, the ultimate goal of which is to return lands to economic circulation through the formation of full-fledged sustainable biogeoceosis. The reclaimed land can be used for recreational, economic and recreational, agricultural and other purposes. In this case, the structure and composition of the reconstructed ecosystems should be as close as possible to the corresponding parameters of the natural biogeocenoses of the region. It should be borne in mind that in anthropogenically formed ecosystems, problems of disturbance of the ecological balance often arise, associated both with the simplification of the trophic webs of endemic species, and with the ill-considered introduction of new 
competing species. In addition, ecotopes reconstructed without taking into account the ecological characteristics of the region may turn out to be unsuitable for habitation of endemic species due to changes in the physicochemical, edaphic and other parameters of the environment. In this regard, the processes of biological reclamation come to the fore: the formation of ecotopes that are maximally correlated with the biological needs of the biocenosis. Thus, the basis in biological land reclamation is the reconstruction of the fertile soil layer as the basis for the formation of sustainable terrestrial ecosystems. To analyze the dynamics of the state of disturbed lands, ecological maps of the Kemerovo region (1995) and statistical reports "On the state and protection of the environment of the Kemerovo region" (2006-2020) were used. In the Kemerovo region, 35-118 thousand hectares are annually classified as disturbed lands. The minimum for this indicator was registered in 2015. A total of 1154.1 thousand hectares were disturbed. Since 2017, the indicator has been steadily growing, reaching 118 thousand hectares in 2020 .

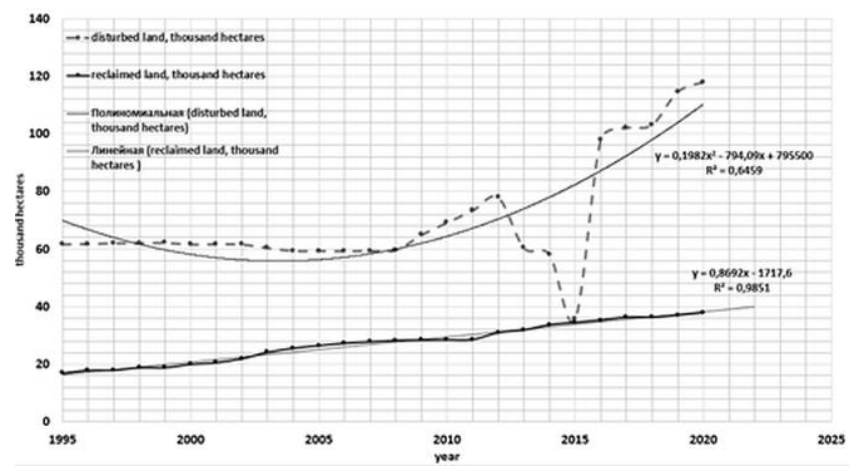

Fig. 1. Dynamics and forecast of processes of disturbance and land reclamation in the Kemerovo region

Over the past 14 years, a little more than $40 \%$ of disturbed lands have been reclaimed 482.8 thousand hectares. The return of land to economic circulation on average over the past 25 years amounted to 27,4 thousand hectares per year. The share of reclaimed land by 2020 decreased to $32 \%$.

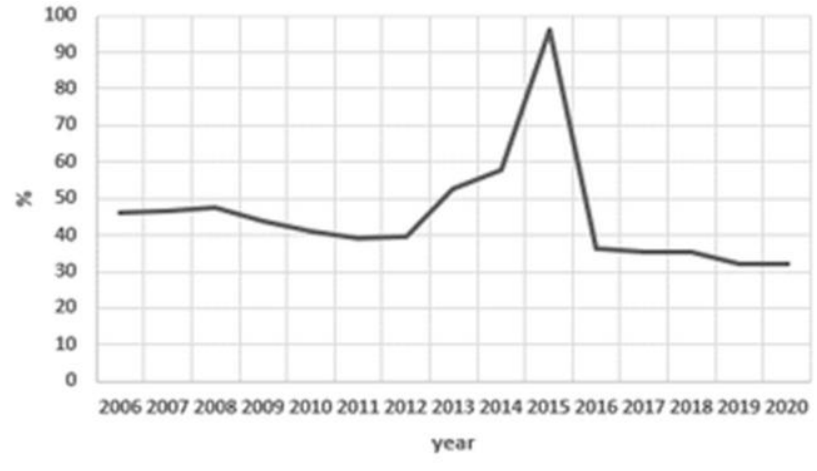

Fig. 2. The share of reclaimed land in Kuzbass

As a result of approximating the function, we obtained a theoretical curve of the dynamics of land disturbance, which can be described by the following formula:

$$
\mathrm{y}=0,1982 \mathrm{x}^{2}-794,09 \mathrm{x}+795500
$$

The coefficient of accuracy of the approximation $\mathrm{R}^{2}=0.6459$ indicates a fairly high degree of compliance of the trend model with the initial data. 
For twenty-five years, there has been a positive trend in the reclamation of disturbed lands. The theoretical curve of the dynamics of work on land reclamation in the Kemerovo region, which can be described by the following formula:

$$
y=0,8692 x-1717,6
$$

The coefficient of reliability of the approximation $\mathrm{R}^{2}$ was 0.9851 , which indicates a high degree of compliance of the trend model with the initial data.

Thus, in 2017-2020 a sharp increase in the area of disturbed lands in Kuzbass was noted, while the rate of reclamation remained at the same level.

\section{Production and consumption waste management in Kuzbass}

Production and consumption waste management is regulated in Kuzbass by the Federal Law of 24.06.98 No. 89-FZ "On Production and Consumption Waste", the Law of the Kemerovo Region of 05.05.2016 No. 28-OZ "On the Delimitation of Powers between Government Bodies of the Kemerovo Region in the field of circulation production and consumption waste "and the program" Management of production and consumption waste, including solid municipal waste, of the Kemerovo region "for 2017 - 2026.

According to clause 8 of Article 12 of the Federal Law of 24.06.98 No. 89-FZ "On Production and Consumption Waste", from January 1, 2017, the disposal of waste containing useful components to be disposed of is prohibited. All municipal solid waste should be sorted before final disposal in order to isolate fractions that can be used and are suitable for recycling. Filed by a number of authors, the composition of solid household waste includes up to $60 \%$ of useful fractions (paper, cardboard, food waste).

Thus, the entire volume of municipal solid waste, from which a useful fraction can be separated, must be processed (sorted) before disposal. On the territory of the Kemerovo region, there are currently only two facilities for processing solid municipal waste with a total capacity of about 165,000 tons per year. The regional waste cadastre, which has been maintained since 2011, includes 452 waste disposal facilities, 185 organizations that receive and process waste (Internet portal of the Ministry of Natural Resources and Ecology of Kuzbass (www.kuzbasseco.ru), section "Waste Management").

At present, $98.1 \%$ of solid municipal waste generated on the territory of the Kemerovo Region is disposed (disposed of) at waste disposal facilities without preliminary treatment. Thus, there is an urgent need to solve both environmental problems in the Kemerovo region.

The author's principles of rational use were developed, the implementation of which will contribute to the improvement of the ecological situation and the mechanisms of implementation:

\section{Principle 1.}

An integrated approach to solving the problems of land reclamation and disposal of solid household waste in a coal-mining region.

There are two ways to solve this problem.

$\checkmark \quad$ To increase soil fertility during reclamation, use useful fractions of solid waste, which must be processed into vermicompost.

$\checkmark \quad$ Alternative use of the discovered lands: their flooding and exploitation for the cultivation of aquaculture facilities. Kuzbass has a successful experience of operating flooded waste pits for fish farming. The principles of biodiversity conservation in hydrobiocenoses, formed as a result of the activities of coal mining and energy enterprises, have been developed and introduced into production $[5 ; 6]$. The prospects of each technogenic reservoir are assessed individually, according to the results of monitoring the 
state of hydrobiogeocenoses by the most acceptable methods, both using remote sensing methods and direct monitoring methods for studying the environmental problems of small technogenic reservoirs $[1 ; 2 ; 3 ; 7 ; 9 ; 11]$.

\section{Principle 2.}

Predicting and regulating the introduction of alien objects. Vermicomposting technology seems to be the most promising for the processing of solid waste into vermicompost: the use of earthworms of the genus Eisenia, widespread in the region, for the destruction of organic matter and obtaining a highly effective fertilizer [16]. As objects of aquaculture in water bodies with a tendency to eutrophication, the most environmentally friendly and economically acceptable method of cleaning water bodies with the help of amelioration fish - the silver carp microphytophage and grass carp macrophytophage. The silver carp microphytophage has few food competitors in the Ob basin, so it will not reduce the productivity of native fish species. The macrophytophagus grass carp, with a lack of preferred plant species, expands the range of nutrition and becomes a benthophage, undermining the food supply of tundra fish. Therefore, the introduction of grass carp into should be carried out taking into account the conditions of each specific reservoir.

\section{Principle 3.}

Environmentally friendly technologies, minimization of emissions into the biosphere.

- disinfection of MSW processing products

- waste-free technologies

- $\quad$ cyclical technologies

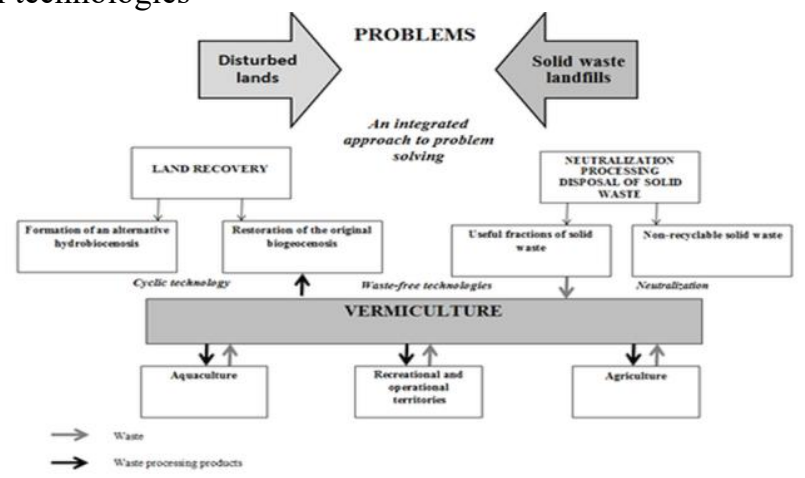

Fig. 3. Scheme of land reclamation and solid waste disposal in Kuzbass

\section{Conclusion}

Thus, to solve the environmental problems of coal-mining regions, principles of rational use have been developed, the implementation of which will help to improve the environmental situation and mechanisms for implementation: an integrated approach to solving the problems of land reclamation and disposal of solid household waste in a coalmining region; forecasting and regulation of the introduction of alien objects; introduction of environmentally friendly technologies to minimize emissions of xenobiotics into the biosphere and decontamination of MSW processing products. 


\section{References}

1. A. Akiyama, Bull. Jap. Soc. scient. Fish, 36, 563 (1970)

2. A. Collin, J. Hench, Remote Sensing.4(12),1425 (2012)

3. A. Minghelli-Roman, A. Goreac, S. Mathieu, M. Spigai, P, Gouton, International Journal of Remote Sensing, 30(1-2), 5737 (2009)

4. I.D. Alborov1 BIO Web of Conferences, 17, 00260 (2020)

5. L. Zakonnova, I. Nikishkin, A. Rostovzev, E3S Web of Conferences, 21, 02015 (2017)

6. L. Zakonnova, I. Nikishkin, L. Stemplewska, A. Chupryakova, E3S WEB OF CONFERENCES. T.F. Gorbachev Kuzbass State Technical University, 02027, (2020)

7. M. Deidda, G. Sanna, Proceedings of the XXII ISPRS Congress. Melbourne, Australia, 153 (2012)

8. M. J.Haigh, Land Deg ra da tion \& De vel op ment, 3 (2006)

9. R. Uma Maheswari R. International Journal of Marine Science, 3(11), (2013)

10. S Oka, et al. Thermal Science, 10(2), 5 (2006)

11. S. Sathyendranath S. IOCCG Report Number 3. Dartmouth, Canada: MacNab Print, 3, $140(2000)$

12. S., Etteieb, S. Magdouli, M. Zolfaghari, S. Brar, Science of the Total Environment, 698(1), (2020)

13. V. Ilinkin, V. Dimitrova ECOLOGIA BALKANICA, 11(2) (2019)

14. V. Ristovi, et al., THERMAL SCIENCE, 14(3) (2010)

15. Z. Strzyszcz, Water, air and Soil Pollution, 91 (1996)

16. K. Petrochenko, et al., Bulgarian Journal of Agricultural Science, 25(4) (2019) 